\title{
Immigration and Ethnic Diversity in England and Wales Examined Through an Area Classification Framework
}

\section{Kitty Lymperopoulou ${ }^{1}$}

Published online: 6 June 2019

(C) The Author(s) 2019

\begin{abstract}
This paper develops an area classification to examine immigration, ethnic diversity, and its social consequences in local authorities of England and Wales. Using a set of demographic, socio-economic, and migration variables drawn from survey and administrative data and cluster analysis methods, it produces a 12-fold classification of local authorities. The classification includes groups of traditional immigrant settlement areas with high flows of migrants of different migration streams and nationalities, smaller urban, and semi-rural areas with high migration rates associated with a dominant migrant group, as well as areas with migration rates close to the national average or below average migration rates. By taking into account the nuances of diversity and immigration and the local socio-economic context in which migrants settle, the classification provides a useful framework towards understanding the different ways immigration can impact on social cohesion and how local policies can be more responsive to the needs of local populations. Examination of attitudes to immigration, perceptions of cohesion, and social mixing suggests that less ethnically diverse local authorities with a dominant migrant group and socio-economically deprived local authorities are most at risk of experiencing higher pressures on social cohesion.
\end{abstract}

Keywords Immigration · Ethnic diversity $\cdot$ Social cohesion · Area classification · England and Wales

\section{Introduction}

The foreign born population in England and Wales has more than doubled over the last two decades, from around 3.6 million in 1991 to 7.5 million in 2011. During this time,

Kitty Lymperopoulou

Kitty.Lymperopoulou@manchester.ac.uk

1 Cathie Marsh Institute for Social Research (CMI), University of Manchester, Humanities

Bridgeford Street, Oxford Road, Manchester M13 9PL, UK 
immigration changed dramatically as a result of the diversification in the composition of the flows of migrants who are increasingly from countries without prior-historical and colonial- links to the UK (Vertovec 2007). These changes involved an acceleration of asylum applications from Africa, Asia, and the Middle East and unprecedented levels of immigration from the EU Accession countries to the UK following the 2004 and $2007 \mathrm{EU}$ enlargements. A defining feature of new immigration has been the settlement of migrants outside traditional immigrant receiving areas. Large numbers of EU Accession migrants settled in rural and coastal areas attracted by favourable employment conditions (Pemberton 2006; Lymperopoulou 2013) while National Asylum Seekers Support Service (NASS) dispersal policies placed large numbers of asylum seekers in deprived and often less ethnically diverse areas (Phillimore and Goodson 2006).

Against the backdrop of new immigration, there has been a lot of interest in its social, economic, political, and cultural consequences. The social impact of immigration - the extent to which immigration is having an impact on social relations and resources in local communities - has been at the heart of public policy debates in the UK. Much attention has focused on the potential negative effects of immigration on social cohesion understood as 'the common values and purpose in society, including a sense of belonging and solidarity for people from diverse backgrounds' (Cheong et al. 2007: 28). Public opinion polls have persistently shown anxieties about levels of immigration and the negative impact of immigrants on local communities, particularly on resources and public services (Duffy and Frere-Smith 2014). Opposition to the large-scale post $\mathrm{EU}$ accession migration is thought to have been one of the main factors behind Brexit, the UK's decision to leave the EU as a result of the 2016 EU membership referendum (Ford and Goodwin 2017).

Much of the political debates about the effects of immigration on cohesion in the UK have been influenced by Robert Putnam's thesis that 'diversity fosters out-group distrust and in-group solidarity' (Putnam 2007: 142). Explanations of the mechanisms through which immigration impacts on social cohesion emphasise the role of 'racial threat' which results in competition for scarce resources and increased prejudices towards minority groups ultimately lowering social cohesion; and the 'contact' hypothesis where interpersonal contact helps dissolve stereotypes increasing interethnic trust and improving cohesion (van der Meer and Tolsma 2014).

There is a growing literature on the relationship between ethnic diversity and social cohesion which has produced contradicting findings about the extent to which immigration impacts negatively on cohesion. The lack of consensus partly reflects the different ways cohesion and ethnic diversity have been operationalised in empirical studies (van der Meer and Tolsma 2014). Most studies to date have used single measures of diversity, for example, the size of the ethnic minority population, fractionalization and segregation indices, to examine the effects of immigration on cohesion (ibid). This is despite recognition that different immigrant and ethnic minority groups, as well as different ethnic mixes in a community, may have differential effects on social cohesion (Laurence 2011: 71). The negative effects of ethnic diversity on cohesion have been found to be greater in US studies than studies in Europe, Australia, Canada and New Zealand (van der Meer and Tolsma 2014). In the UK, studies have generally shown that it is area deprivation and not ethnic diversity which erodes social cohesion (Letki 2008; Laurence 2011; Becares et al. 2011; Sturgis et al. 2011). In assessing the 
social impacts of immigration it is therefore important to examine differences in the flows and characteristics of migrants as well as the context of the different places in which they settle. This can provide insights for understanding the nature of immigration in different area socio-economic contexts and the factors associated with the differential impact of immigration on local communities.

This paper develops an area classification using information on the demographic, socio-economic, and migration characteristics of local authority districts in England and Wales to improve understanding about the nature and consequences of immigration in local areas. The classification reveals a much more nuanced picture of immigration and diversity and can help identify the ways immigration flows are likely to affect local areas in the future and assist the planning of services in these areas. Unlike previous studies which have used single indicators of diversity to explore the relationship between immigration and social cohesion, the classification approach developed in this paper provides a more comprehensive account of patterns of immigration in different local contexts, which we show is useful in identifying where immigration is likely to have a greater impact on social cohesion. The next section reviews the literature on the determinants of the social impacts of immigration, followed by a discussion of the data and methods. We then present the classification results and examine attitudes to immigration, perceptions of cohesion and levels of social mixing across classification areas. The final section concludes with a discussion of the implications of the results and the utility of the classification for policy-makers and service providers.

\section{The Factors Determining the Social Impacts of Immigration}

The social impacts of immigration are not well understood, as they are the outcome of a complex interplay between a range of characteristics associated with migrant populations, established populations, and the places where they settle. The socio-economic characteristics of migrants, including country of birth and nationality which are often indicative of rights and entitlements in the receiving country and cultural distance, in terms of for example, language, education, and religion (Zorlu and Mulder 2008), influence local attitudes towards immigration, and processes of integration and social cohesion. Equally, features of the social environment such as levels of deprivation, the existence of social networks and support, as well as socio-cultural and historical community features, such as norms relating to shared identity and attitudes towards diversity, would be expected to influence local experiences of immigration (Robinson and Reeve 2006; Robinson 2010). The local context in terms of experience of immigration in the past is important for processes of integration, as it signifies the presence of social support, community infrastructures, shared resources and services available to immigrant communities which enhance their well-being, particularly in the early stages of migration by protecting them from alienation and discrimination (Phillips 2007; Spicer 2008). Inter-ethnic social contact and social cohesion will also be expected to be higher in ethnically diverse areas (Laurence and Heath 2008). In these areas, community tensions attributed to the arrival of migrants can be managed and negotiated since local agencies and service providers are likely to have experience in dealing with pressures associated with the arrival of new groups and adjust more quickly to the growing demand for services. 
Many migrants arrive in the UK with limited financial assets and initially move to deprived areas to benefit from the availability of cheap housing. These are areas typically experiencing poor environmental conditions, poor housing, poor employment, high crime levels, and poor services. Community tensions arise from feelings that the needs of migrants are being prioritised over the needs of long-term residents despite the existence of pressures that pre-date the arrival of migrants (Robinson and Reeve 2006; Audit Commission 2007; Pemberton and Stevens 2007). The social impacts of immigration are often interlinked with economic conditions - established residents blame new immigrants for economic hardship or compete with them for scarce resources (Quillian 1995). In areas with migrant-dense industries (Green et al. 2007) for example, there may be fears of displacement of local workers, increased competition for jobs, lower wages and higher unemployment which create animosity towards migrants.

Perceived competition over social housing allocation is another source of poor community relations, particularly in social housing areas with a high visibility of migrants and asylum seekers and where there is high demand for social housing (Robinson and Reeve 2006). In areas experiencing housing pressures, there are also fears that higher rental prices are pushing local residents out of the market and increasing concerns about the use of unsuitable housing as Houses of Multiple Occupations (HMOs) by private landlords wishing to maximise profits (Robinson et al. 2007; Pemberton and Stevens 2007).

The local experiences of immigration are likely to differ in urban and rural areas and in areas with different population turnover rates. The higher visibility of migrants in rural areas may increase racial harassment while the lack of community facilities and resources may suggest fewer opportunities for contact which may perpetuate hostility towards migrants and their isolation. The arrival of migrants in areas experiencing particularly high or low population turnover may also be problematic since it can cause disruption of social ties and relations, including trust, tolerance and familiarity, breed suspicion, and accentuate differences (Livingston et al. 2008).

Public attitudes towards immigration highlight the rate of population change as a main driver of hostility towards immigration (Duffy and Frere-Smith 2014). The effect of high turnover on cohesion depends on both the scale of flows and the composition of populations (migrants and non-migrants) moving in and out of local areas. The temporary settlement of some migrant groups, such as seasonal workers, may have a disruptive effect on social cohesion by increasing turnover levels. Population turnover can also create challenges for public service providers. School and healthcare providers, for example, have been reporting population turnover as a main cause of disruption of existing services while it is also hindering their ability to develop knowledge to meet the needs of new populations (House of Lords Select Committee on Economic Affairs 2008; George et al. 2012). The adaptability and responsiveness of public service providers to deal with immigration and population turnover will influence local cohesion (Saggar and Somerville 2012). The local experiences of immigration, however, will depend on the demographic characteristics of local populations. In areas where there are large differences in the age profile of new and established populations for example, there may be higher pressures on public services and social cohesion. Perceptions of cohesion and tolerance towards new groups will typically vary by age, with younger people generally being more likely to be accepting of new immigrants than older people (Sturgis et al. 2014). 
To examine immigration and its social consequences in England and Wales this paper uses an area classification approach which provides 'a unique way of bringing together spatial patterns from a range of variables, and identifying similarities and dissimilarities between areas' (Vickers and Rees 2007; 380). Previous attempts to better understand the nature and consequences migration in local areas in the UK have made use of existing area classifications (Dennett and Stillwell 2010; Raymer and Giulietti 2009) or developed new area classifications (Dennett and Stillwell 2011, Robson et al. 2008), although they have all focused on internal rather than international migration patterns. Similarly, area classifications developed for the purposes of examining the relationship between diversity and social cohesion have focused on specific aspects of diversity such as the composition of ethnic groups which does not effectively account for the nuances and diversity of contemporary migration across local communities in the UK (for example, Laurence 2011; Becares et al. 2011). This is the first classification that attempts to capture international migration in different local contexts to provide insights about the different ways in which immigration impacts on local communities across England and Wales.

\section{Data and Methods}

This paper explores the patterns of immigration and its consequences by drawing on a variety of data sources on international migration for local authorities in England and Wales. Office for National Statistics (ONS) migration estimates, Department for Work and Pensions (DWP), National Insurance numbers (NINOs), and Home Office asylum statistics were used to capture flows of migrants of different migration streams (dependants, students, workers, and asylum seekers) and of different nationalities (European, New World, EU Accession, African, and Asian countries). Local authority districts are commonly used as approximations of the wider areas of socio-economic opportunity within which neighbourhoods sit (Kearns and Parkinson 2001) and provide the broader context (for example, schools, workplaces, and public spaces) where everyday interactions take place and where attitudes towards immigrant groups are formed (Quillian 2014). The analysis only covered England and Wales due to inconsistency or unavailability of data for Scotland and Northern Ireland.

One of the main limitations of using multiple sources of information on immigration is that they capture different types of migrants, defined in different ways, for example by country of birth or nationality. However, the UK Census, which is the most complete and accurate source of information on immigration in the UK, quickly becomes outdated as it is conducted every 10 years. ${ }^{1}$ Another limitation with the Census is that it does not capture key migration characteristics, such as immigration route, that are important for determining the local impact of immigration. The advantages of the classification outlined in this paper in relation to existing classifications are discussed in the next section.

The 2001 Census was used to take into account the characteristics of the pre-existing population including age structure and housing tenure as well as the history of ethnic

\footnotetext{
${ }^{1}$ Immigration estimates from the 2011 Census were not available at the time of the development of the classification so it was not possible to include more recent estimates in the analysis.
} 
minority settlement. DWP Benefit statistics were used to measure levels of worklessness to capture local area socio-economic deprivation. The local employment structure is captured through a set of indicators drawn from the Business Register and Employment Survey (BRES). BRES estimates were used to estimate employment in migrantdense industries: industries where migrant workers have a greater propensity to be employed than their UK national counterparts. Six industries were identified as migrant-dense: transport and storage; accommodation and food services; information and communication; financial and insurance; business administration and support services; and health. In order to capture employment in manufacturing, a measure of the proportion of employees in the manufacturing sector was used.

The six fold Department for Environment, Food and Rural Affairs (DEFRA) ruralurban classification for local authorities was used to identify areas with different population thresholds. ${ }^{2}$ Major urban areas are those with either 100,000 people or $50 \%$ of their population in urban areas with a population of more than 750,000. Large urban areas are those with either 50,000 people or $50 \%$ of their population in 1 of 17 urban areas with a population between 250,000 and 750,000. Other urban areas have less than $26 \%$ of their population in rural settlements and larger market towns. Significant rural areas are those with more than $26 \%$ of their population in rural settlements and larger market towns. Rural-50 areas are those with at least $50 \%$ but less than $80 \%$ of their population in rural settlements and larger market towns. Finally, Rural-80 areas have at least $80 \%$ of their population in rural settlements and larger market towns.

The classification was obtained using K-means clustering methods applied to the 20 variables shown in Table $1 .^{3}$ Hierarchical cluster analysis with Ward's method was first applied to the log transformed and standardized (z-scores) variables in order to weight them according to their variability (Everitt and Dunn 2001). The squared Euclidean distance was used to measure similarity between clusters, with the optimal number of clusters determined by examining the coefficients of change in the agglomeration schedule, which plots the number of clusters against the within-cluster sum of squares at each stage when clusters are combined, and profiling and discriminating between groups which suggested a 12 cluster solution. ${ }^{4}$

K-means clustering was used to optimise the 12-cluster solution obtained from the hierarchical cluster analysis. Combining hierarchical and non-hierarchical (K-means) cluster methods is a common approach in the derivation of area classifications producing valid and reliable cluster results with homogenous clusters (Ward's method) and ensuring each district is in the right cluster (K-means) (see ONS 2005). The K-means algorithm essentially re-calculates the distance from each district to each cluster

\footnotetext{
${ }^{2}$ The DEFRA urban-rural classification corresponds to local authority districts in England. The same methodology was applied to Wales by the Wales Agricultural and Rural Affairs Statistics team to produce a single rural-urban indicator for England and Wales for the purposes of this study.

3 These are a subset of 75 indicators selected on the basis of inspection of descriptive statistics, correlation analysis and principal component analysis (PCA), which aimed to exclude irrelevant or masking variables that would add little information to the identification of groupings within the data (Vickers and Rees 2007). Indicators measuring change in migration flows over time were excluded on this basis.

${ }^{4}$ The agglomeration schedule is available upon request. The cluster efficiency was determined by applying other clustering methods (such as the Average Linkage Method) which also suggested that the 12-cluster solution was the most parsimonious solution.
} 
Table 1 List of variables in the classification

Migrant workers: Short-term and long-term migrant workers per 1000 resident population

2010 ONS

Migrant students: Short-term and long-term migrant students per 1000 resident population

Migrants aged 60 or above per 1000 resident population (Elderly migrants)

2010 ONS

Migrants aged 0 to 16 per 1000 resident population (Child migrants)

2010 ONS

Asian migrants: Migrants from Asia and the Middle East per 1000 resident population

2010 ONS

African migrants: Migrants from Africa per 1000 resident population

2010 DWP

EU Accession migrants: Migrants from the EU Accession countries per 1000 resident population

European migrants: Migrants from Europe (excluding EU Accession countries) and the 2010 DWP New World per 1000 resident population

Supported asylum seekers: Asylum seekers receiving Section 95 support 25 per 1000 resident population

2010 DWP

2010 DWP

Turnover: Gross migrant inflows and outflows per 1000 resident population

Pre-existing migrants: Proportion of people born outside the UK

2010 Home

Office

People aged 65 plus: Proportion of people aged 65 or above

2010 ONS

2001 Census

People aged 25 to 34: Proportion of people aged 25 to 34

2001 Census

People aged 0 to 14: Proportion of people aged 0 to 14

2001 Census

2001 Census

Worklessness: Proportion of people claiming Incapacity Benefit (IB), Jobseeker's

2010 DWP

Allowance (JSA) and Severe Disablement Allowance (SDA)

Social renting: Proportion of households renting from a social housing landlord

2001 Census

Private renting: Proportion of households renting privately or living rent free

2001 Census

Manufacturing: Proportion of employees in manufacturing

2010 BRES

Migrant-dense industries: Proportion of employees in migrant-dense industries

2010 BRES

Rural/urban: Rural-urban LA classification

2001 DEFRA

centroid and moves districts that are not in the cluster that they are closest to. This process is repeated until the centroids remain relatively stable.

\section{A New Classification of Local Authorities in England and Wales}

The cluster analysis produced a 12-fold classification of local authorities on the basis of international migration flows and local area socio-economic conditions. Figure 1 shows the spatial distribution of the classification areas across England and Wales while Fig. 2 shows the radial plots for every classification area which represent the standardized values $(Z)$ scores of each of the variables. Positive values indicate a value above the England and Wales average and negative values indicate below average values. Table 2 provides a summary of the characteristics of each classification group.

The 12 groups of local authorities can be classified on the basis of their flows and stocks of international migrants as 'high', 'moderate' and 'low' migration. 'High' migration groups have migration rates that are well above the national average. This means that in these groups, there is one or more migration variable with a rate above 
Local Authority Classification

M Superdiverse London

$\square$ Cosmopolitan London and Periphery

[..... London Suburbs and Satellite Towns

Diverse Conurbation Centres

III High Turnover Provincial and Student Towns

$\square$ Asylum Dispersal Areas

Migrant Worker Towns and Countryside

Rural and Coastal Retirement Areas

2 New,Large, Free-standing and Commuter Towns

$\square$ Prosperous Small Towns

$\square$ Industrial and Manufacturing Towns

$\square$ Low Migration Small Towns and Rural Areas

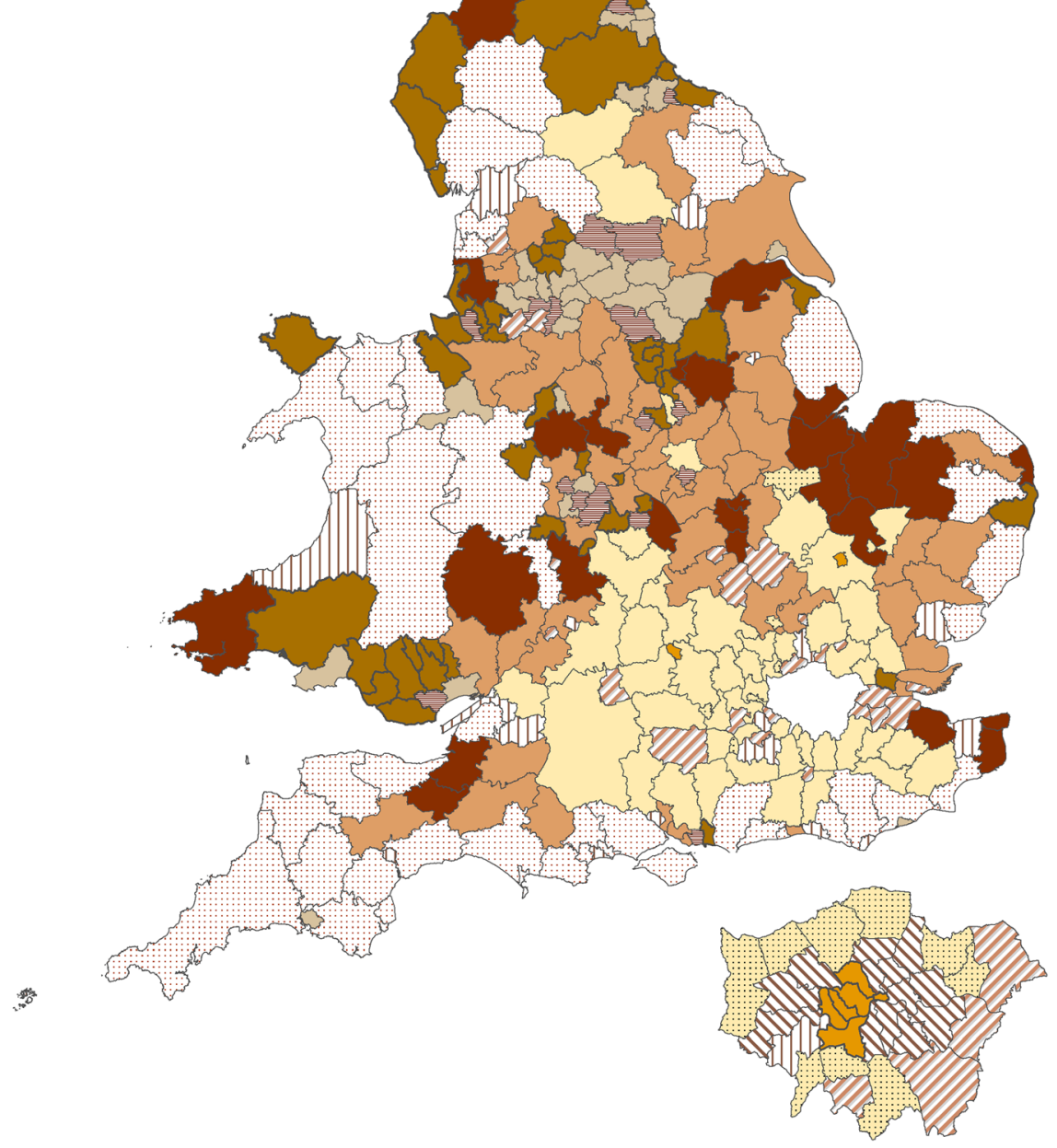

Fig. 1 Local authority classification

the national average, that is, greater than 0.5 standard deviations above the England and Wales mean. In 'moderate' migration groups, migration rates are close to the national average and range from 0.5 standard deviations below to 0.5 standard deviations above the mean for England and Wales. In 'low' migration groups, migration rates are well below the England and Wales average and, or less than 0.5 standard deviations below the mean. 

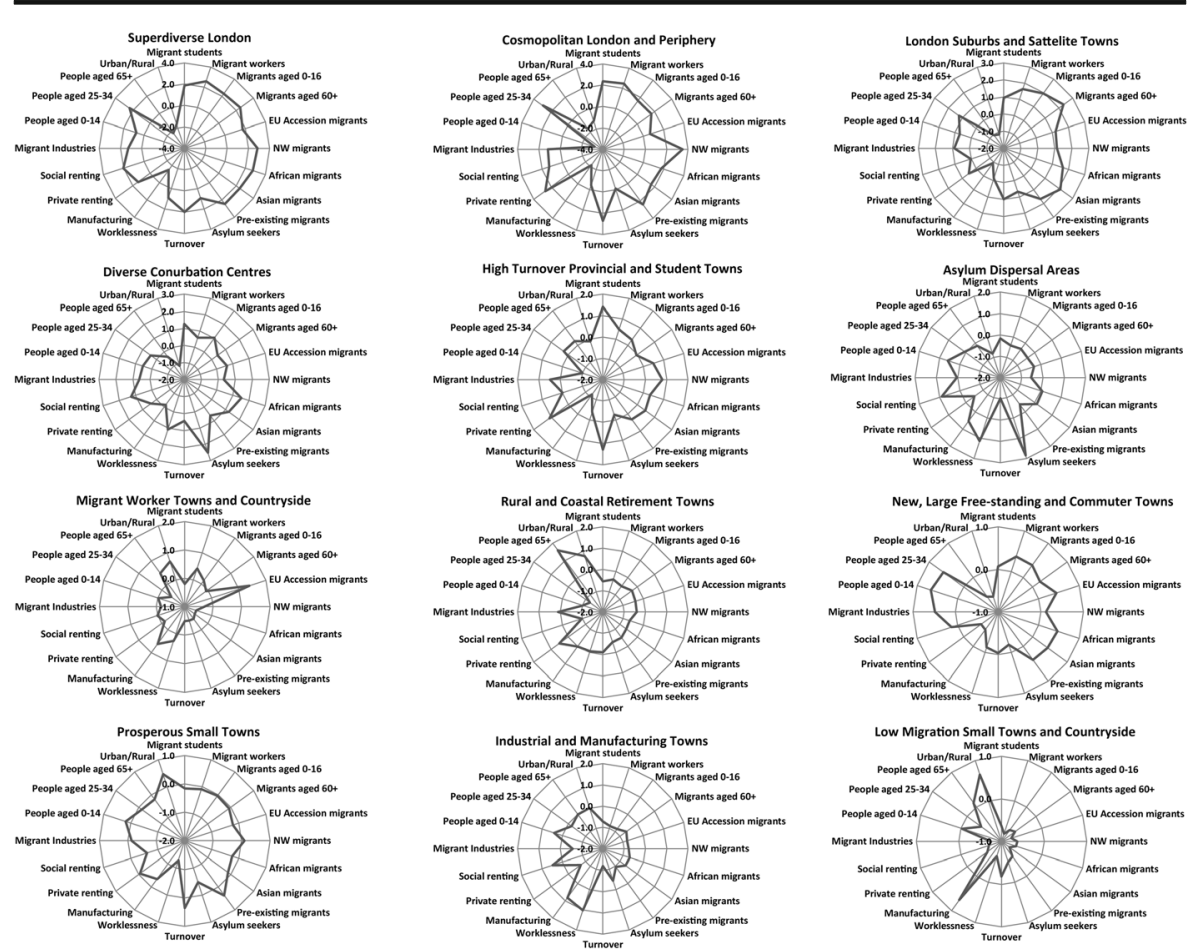

Fig. 2 Local authority classification summary radial plots

There are seven groups that can be classified as 'high' migration comprising 127 local authorities (36\%) in England and Wales. Four of these groups comprise London boroughs and other conurbation centers with long histories of migration and high flows of recent migrants of different migration streams and nationalities. They include 'Superdiverse London', a group of London Boroughs such as Brent, Ealing, Hackney, Tower Hamlets and Waltham Forest characterised by diverse flows of migrants and higher levels of previous immigration than other groups. 'Cosmopolitan London and Periphery', a group comprising inner London Boroughs such as Camden, Kensington and Chelsea, as well as Cambridge and Oxford, is also defined by high migration rates particularly for students, migrant workers, and migrants originating in Europe and the New World. 'London Suburbs and Satellite Towns' comprise mainly outer London boroughs such as Croydon, Enfield, and Harrow and neighboring towns such as Slough, Reading, and Luton and have high migration rates for all groups of migrants particularly for elderly and children migrants. 'Diverse Conurbation Centres' comprise local authorities in large conurbations in the North of England and the Midlands including Bradford, Birmingham, Manchester and Liverpool. These are areas with above average levels of worklessness and social housing and higher migration rates for asylum seekers, Asian and African migrants.

A further three 'high' migration groups comprise of local authorities characterised by a dominant migrant group so that there are well above average migration rates for one group but average or below average migration rates for other migrant groups. These local authorities are typically located outside traditional immigrant settlement 
Table 2 Local Authority classification description

\begin{tabular}{|c|c|c|c|}
\hline Group name & & Description & Membership \\
\hline \multirow[t]{7}{*}{$\begin{array}{l}\text { 'High' } \\
\text { Migra- } \\
\text { tion }\end{array}$} & Superdiverse London & $\begin{array}{l}\text { Urban areas with very high migration rates for all } \\
\text { migrant types and high population turnover. } \\
\text { Levels of previous migration are higher than in } \\
\text { any other cluster. More young people, fewer } \\
\text { elderly people. }\end{array}$ & $\begin{array}{l}13 \text { local } \\
\text { authorities } \\
\text { Most typical: } \\
\text { Waltham } \\
\text { Forest } \\
\text { Least typical: } \\
\text { Newham }\end{array}$ \\
\hline & $\begin{array}{l}\text { Cosmopolitan London } \\
\text { \& Periphery }\end{array}$ & $\begin{array}{l}\text { Urban areas with high migration rates for students, } \\
\text { migrant workers and migrants from Europe and } \\
\text { the New World. High levels of migration in the } \\
\text { past and population turnover. More young } \\
\text { people and private renters. }\end{array}$ & $\begin{array}{l}8 \text { local } \\
\text { authorities } \\
\text { Most typical: } \\
\text { Kensington \& } \\
\text { Chelsea } \\
\text { Least typical: } \\
\text { City of } \\
\text { London }\end{array}$ \\
\hline & $\begin{array}{l}\text { London Suburbs \& } \\
\text { Satellite Towns }\end{array}$ & $\begin{array}{l}\text { Urban areas with high migration rates for } \\
\text { dependants, migrant workers, African and Asian } \\
\text { migrants. High levels of pre-existing migration, } \\
\text { younger population with more children and } \\
\text { younger people than average. }\end{array}$ & $\begin{array}{l}15 \text { local } \\
\text { authorities } \\
\text { Most typical: } \\
\text { Croydon } \\
\text { Least typical: } \\
\text { Rushmoor }\end{array}$ \\
\hline & $\begin{array}{l}\text { Diverse Conurbation } \\
\text { Centres }\end{array}$ & $\begin{array}{l}\text { Urban areas with high migration rates for African } \\
\text { and Asian groups, migrant children and students. } \\
\text { Asylum seekers are overrepresented. High levels } \\
\text { of worklessness and social housing. }\end{array}$ & $\begin{array}{l}17 \text { local } \\
\text { authorities } \\
\text { Most typical: } \\
\text { Birmingham } \\
\text { Least typical: } \\
\text { Manchester }\end{array}$ \\
\hline & $\begin{array}{l}\text { High Turnover } \\
\text { Provincial \& } \\
\text { Student Towns }\end{array}$ & $\begin{array}{l}\text { High levels of turnover, private renting, and student } \\
\text { migration. There are below average numbers of } \\
\text { people employed in manufacturing and fewer } \\
\text { children. }\end{array}$ & $\begin{array}{l}20 \text { local } \\
\text { authorities } \\
\text { Most typical: } \\
\text { Cheltenham } \\
\text { Least typical: } \\
\text { Isles of Scilly }\end{array}$ \\
\hline & $\begin{array}{l}\text { Asylum Dispersal } \\
\text { Areas }\end{array}$ & $\begin{array}{l}\text { Higher proportion of supported asylum seekers than } \\
\text { any other cluster and high levels of worklessness } \\
\text { and social housing. Population turnover is below } \\
\text { average. }\end{array}$ & $\begin{array}{l}28 \text { local } \\
\text { authorities } \\
\text { Most typical: } \\
\text { Rotherham } \\
\text { Least typical: } \\
\text { Blackburn }\end{array}$ \\
\hline & $\begin{array}{l}\text { Migrant Worker } \\
\text { Towns \& } \\
\text { Countryside }\end{array}$ & $\begin{array}{l}\text { High migration rates for EU Accession migrants, } \\
\text { lower levels of population turnover and above } \\
\text { average levels of employment in manufacturing. } \\
\text { More rural areas. }\end{array}$ & $\begin{array}{l}26 \text { local } \\
\text { authorities } \\
\text { Most typical: } \\
\text { Dover } \\
\text { Atypical: Boston }\end{array}$ \\
\hline $\begin{array}{l}\text { 'Moderate' } \\
\text { Migra- } \\
\text { tion }\end{array}$ & $\begin{array}{l}\text { Rural \& Coastal } \\
\text { Retirement Areas }\end{array}$ & $\begin{array}{l}\text { Rural and coastal areas with moderate migration } \\
\text { levels. Migrant students, African and Asian } \\
\text { migrants are underrepresented. More elderly } \\
\text { people, fewer people in social housing and more } \\
\text { people in the private rented sector. }\end{array}$ & $\begin{array}{l}44 \text { local } \\
\text { authorities } \\
\text { Most typical: } \\
\text { Teignbridge } \\
\text { Least typical: } \\
\text { Shepway } \\
28 \text { local } \\
\text { authorities }\end{array}$ \\
\hline
\end{tabular}


Table 2 (continued)

\begin{tabular}{|c|c|c|c|}
\hline \multicolumn{2}{|l|}{ Group name } & \multirow{2}{*}{$\begin{array}{l}\text { Description } \\
\text { Migration and turnover rates are close to the } \\
\text { national average. Slightly higher than average } \\
\text { proportion of children and elderly people. }\end{array}$} & \multirow{2}{*}{$\begin{array}{l}\text { Membership } \\
\text { Most typical: } \\
\text { Dartford } \\
\text { Least typical: } \\
\text { Broxbourne }\end{array}$} \\
\hline & $\begin{array}{l}\text { New, Large, } \\
\text { Free-standing \& } \\
\text { Commuter Towns }\end{array}$ & & \\
\hline & $\begin{array}{l}\text { Prosperous Small } \\
\text { Towns }\end{array}$ & $\begin{array}{l}\text { Rates of current and past migration for all new } \\
\text { migrant types are close to the national average. } \\
\text { Low levels of worklessness and social rented } \\
\text { housing. }\end{array}$ & $\begin{array}{l}49 \text { local } \\
\text { authorities } \\
\text { Most } \\
\text { Typical:West } \\
\text { Berkshire } \\
\text { Least typical: } \\
\text { Forest Heath }\end{array}$ \\
\hline \multirow[t]{2}{*}{$\begin{array}{l}\text { 'Low' } \\
\text { Migra- } \\
\text { tion }\end{array}$} & $\begin{array}{l}\text { Industrial \& } \\
\text { Manufacturing } \\
\text { Towns }\end{array}$ & $\begin{array}{l}\text { Below average migration rates for all migrant } \\
\text { groups, high levels of worklessness and above } \\
\text { average employment in manufacturing. Low } \\
\text { population turnover and fewer people in the } \\
\text { private rented housing sector. }\end{array}$ & $\begin{array}{l}46 \text { local } \\
\text { authorities } \\
\text { Most typical: } \\
\text { Ashfield } \\
\text { Least typical: } \\
\text { Pendle }\end{array}$ \\
\hline & $\begin{array}{l}\text { Low Migration Small } \\
\text { Towns \& Rural } \\
\text { Areas }\end{array}$ & $\begin{array}{l}\text { Below average migration rates for all migrant } \\
\text { groups, above average employment in } \\
\text { manufacturing. Below average levels of } \\
\text { workless and households in rented } \\
\text { accommodation. Mainly rural areas. }\end{array}$ & $\begin{array}{l}54 \text { local } \\
\text { authorities } \\
\text { Most typical: } \\
\text { Stroud } \\
\text { Least typical: } \\
\text { Oadby and } \\
\text { Wigston }\end{array}$ \\
\hline
\end{tabular}

areas. 'High Turnover Provincial and Student Towns' include coastal and semi-rural areas such as Cheltenham, Exeter, Lancaster, Southampton and York, which are characterised by high levels of student migration, and moderate migration flows for other migrant types. 'Asylum Dispersal Areas' are largely deprived former industrial towns such as Bolton, Plymouth, Rotherham and Swansea, where supported asylum seekers are overrepresented. 'Migrant Worker Towns and Countryside' are predominantly rural and semi-rural areas such as Boston, Dover, Fenland and Rugby with high levels of migration from the EU Accession countries and below average levels of migration from other countries. These seven 'high' migration local authority groups account for around a third of all local authorities in England and Wales.

The local authorities in the next three groups comprise of 121 local authorities $(35 \%)$ of mainly rural and coastal areas, free-standing and commuter towns. In all three groups, there are 'moderate' migration levels which are close to the England and Wales average. The population tends to be older than the England and Wales average in two of the 'moderate' migration local authority groups, particularly in 'Rural and Coastal Retirement Towns' which include Arun, Chichester, Cornwall and Teignbridge, where there are more elderly people than average and fewer young people and children. 'New, Large Free-standing and Commuter Towns' comprise of local authorities such as Crawley, Dartford, Gloucester, Ipswich, Warrington and Woking that are fairly typical of the national average in terms of their socioeconomic profile and migration rates, while 'Prosperous Small Towns' include 
mainly rural and semi-rural areas such as the Cotswolds, St Albans and West Berkshire located in the South of England with low levels of worklessness and social rented housing.

The last two local authority groups comprise of the remaining 100 districts (29\%) of largely former industrial and manufacturing towns distributed across England and Wales. These groups can be characterised as 'low' migration - they have below average migration rates for all migrant groups and little history of immigration. 'Industrial and Manufacturing Towns' are local authorities characterised by high levels of worklessness and above average levels of employment in manufacturing while 'Low Migration Small Towns and Rural Areas' are geographically spread across England and Wales and comprise of mainly rural local authorities with below average levels of worklessness (see Table 2).

The 12-fold classification produces a useful framework for understanding migration patterns across localities in England and Wales. Unlike previous area classifications it places more emphasis on different dimensions of migration such as migration stream and nationality, and combines local migration and socioeconomic characteristics to identify groups of areas with distinct migration profiles. A comparison of the results with the 2011 ONS UK area classification ${ }^{5}$ highlights important differences in this respect. It also shows many similarities despite differences in the variables used which gives additional weight to the classification. For example, there are commonalities between the 'high' migration areas associated with multiple migrant types, particularly London Boroughs which form separate groups in both classifications, although they do not necessarily include the same London Boroughs. The highest consistency is observed for the 'moderate' migration groups with membership in two groups in the UK area classification closely matching the 'New, Large, Free-standing \& Commuter Towns' and the 'Prosperous Small Towns' groups. There is also some overlap in the areas classified as rural, coastal and industrial and mining although the classification developed in this paper classifies several of these areas as 'high' migration. The largest differences between the two classifications are observed in terms of the three local authority groups where 'high' migration flows are associated with a dominant migrant type: 'High Turnover Provincial \& Student Towns', 'Asylum Dispersal Areas' and 'Migrant Worker Towns \& Countryside'. These groups are meaningful in terms of what is known about the distribution of different groups of migrants (migrant workers, migrant students and asylum seekers) across the UK. The classification developed in this paper therefore provides a better understanding about the local experiences of recent immigration across different localities in England and Wales.

The next section discusses the ways in which immigration is likely to impact across the 12 local authority groups, given their distinct socio-economic profiles, and examines the potency of the classification and its relevance for understanding patterns of immigration and its local consequences in England and Wales.

\footnotetext{
5 There are 13 classification 'groups' in the UK area classification for England and Wales (excluding Scotland and N.Ireland) drawn from analysis of 59 variables from the 2011 Census. The UK area classification is a three-tier classification system comprising of supergroups, groups and subgroups. We use the middle tier classification for comparison purposes which produces a similar number of groups with the classification presented in this paper.
} 


\section{Exploring the Social Impacts of Immigration Across Classification Areas}

Perceptions about the negative impact of immigration on employment and housing are the most frequently reported sources of community tensions (Robinson and Reeve 2006). The concentration of EU Accession migrants in poor quality and overcrowded private accommodation, and in 'beds in sheds', have been frequently cited sources of conflict between residents in local areas (Robinson and Reeve 2006; Institute of Community Cohesion 2007). The high visibility of some migrant groups such as asylum seekers and refugees in social and assisted housing is also thought to be creating resentment towards migrants (Robinson and Reeve 2006). Higher levels of deprivation and concentrations of disadvantaged migrant groups may therefore impact negatively on cohesion. The impact of immigration on cohesion would be expected to be higher in local authorities experiencing high migration levels and poor social and economic conditions, particularly if they have had little experience of immigration in the past, since deprivation undermines cohesion (Laurence and Heath 2008; Becares et al. 2011; Sturgis et al. 2014).

In terms of the classification, these propositions suggest that 'Asylum Dispersal Areas' which comprise local authorities with higher levels of social housing and worklessness and concentrations of asylum seekers, are likely to experience higher pressures on cohesion, which are likely to be intensified as a result of fewer opportunities for socialisation, social support, and contact between communities (Spicer 2008). The presence of migrant groups and asylum seekers who are more likely to be concentrated in the social housing sector may be a source of neighborhood tensions associated with competition for resources and the increasing shortage of social housing across the UK. In 'Diverse Conurbation Centres' higher levels of deprivation and concentrations of more disadvantaged migrant groups may also impact negatively on cohesion but poor community relations may be managed more effectively in these areas as they have a longer history of immigration.

The impact of immigration on public resources is also likely to be higher in areas with high overall turnover levels such as in 'London Suburbs and Satellite Towns' and 'High Turnover Provincial and Student Towns' and where migration is likely to be associated with seasonal and temporary work as in 'Migrant Worker Towns and Countryside'. In these areas service providers might be faced with a disruption of existing services, and have difficulties in developing new services to meet the needs of new populations. The negative impact of population turnover on cohesion is likely to be intensified in less ethnically diverse areas with older populations which have attracted higher numbers of migrants (as in 'Migrant Worker Towns and Countryside') where attitudes towards immigration are less likely to be favourable (Sturgis et al. 2014).

In contrast, the impact of immigration on cohesion would be expected to be lower in the classification groups comprising London Boroughs such as 'Superdiverse London' and 'Cosmopolitan London and Periphery'. The areas in these groups have long histories of immigration and are comprised of ethnically diverse and typically young populations. They have also attracted larger numbers of economic migrants, particularly from Europe and the New World who may have human capital including language skills and other resources upon arrival to the UK. 'High Turnover Provincial and Student Towns' would also be expected to be comprised of migrants with English 
language fluency which is critical for the development of social networks in the receiving country and facilitates integration and cohesion. ${ }^{6}$

The extent to which there are variations in levels of social cohesion across the classification areas can be assessed by examining attitudes towards immigration, and resident perceptions of cohesion and social mixing. Analysis of the 2010/11 Citizenship Survey $^{7}$ suggests that there is large variation in attitudes towards migrants across the groups of local authorities in line with expectations about the differential impact of immigration on cohesion in different area socio-economic contexts, particularly in terms of the composition of migrants, the history of immigration and levels of socioeconomic deprivation.

As shown in Fig. 3, there are more favorable attitudes towards immigration in ethnically diverse and less deprived local authorities that have attracted higher levels of immigration: around a third of White British people living in 'Superdiverse London' and 'Cosmopolitan London and Periphery' areas believe immigration should be reduced a lot. In comparison, 6 in 10 White British people in areas with high immigration and lower ethnic diversity levels or higher deprivation levels, such as those in 'Asylum Dispersal Areas', 'Diverse Conurbation Centres' and 'Migrant Worker Towns \& Countryside' think immigration should be reduced a lot.

Perceptions of social cohesion are commonly measured as the degree to which people think their local area is a place where people from different backgrounds get on well together and where people respect ethnic differences (Saggar et al. 2012). As shown in Fig. 3, perceptions of cohesion are higher in high migration ethnically diverse areas, and in moderate and low migration areas particularly in rural and affluent areas. Perceptions of social cohesion are lower in 'Asylum Dispersal Areas', 'Diverse Conurbation Centres' and 'Migrant Worker Towns \& Countryside' than in any other classification area. Around $80 \%$ of people in 'Asylum Dispersal Areas' and 'Migrant Worker Towns \& Countryside' believe their local area is a place where people from different backgrounds get on well together compared with $97 \%$ of people in 'Cosmopolitan London \& Periphery'. Similarly, $82 \%$ of people in Asylum Dispersal Areas believe residents in their local area respect ethnic differences compared with $92 \%$ of people in 'Cosmopolitan London \& Periphery'.

Social mixing between ethnic and religious groups is also highest in high migration areas particularly in the most ethnically diverse local authorities. Just a fifth of people in the three London groups stated that they never mix with people from different ethnic and religious groups. In contrast, more than half of people in deprived local authorities, particularly those in 'Industrial \& Manufacturing Towns' (57\%) and 'Asylum Dispersal Areas' (54\%) and people in Rural \& Coastal Retirement Areas (55\%) stated that they never mix socially with people from different ethnic and religious groups than people in other areas.

These differences across the classification areas provide evidence that the social impacts of immigration differ depending on the local socio-economic context in line with differences in the characteristics of migrants and the characteristics of the places in which they settle. High levels of immigration in areas with different population characteristics are associated

\footnotetext{
${ }^{6}$ Evidence from the 2011 Census on the language fluency of migrants across classification areas (not presented here due to space considerations) supports these propositions.

${ }^{7}$ Department for Communities and Local Government and Ipsos MORI, Citizenship Survey, 2009-2011: Secure Access [computer file]. Colchester, Essex: UK Data Archive [distributor], October 2013. SN: 7403, https://doi.org/10.5255/UKDA-SN-7403-1
} 


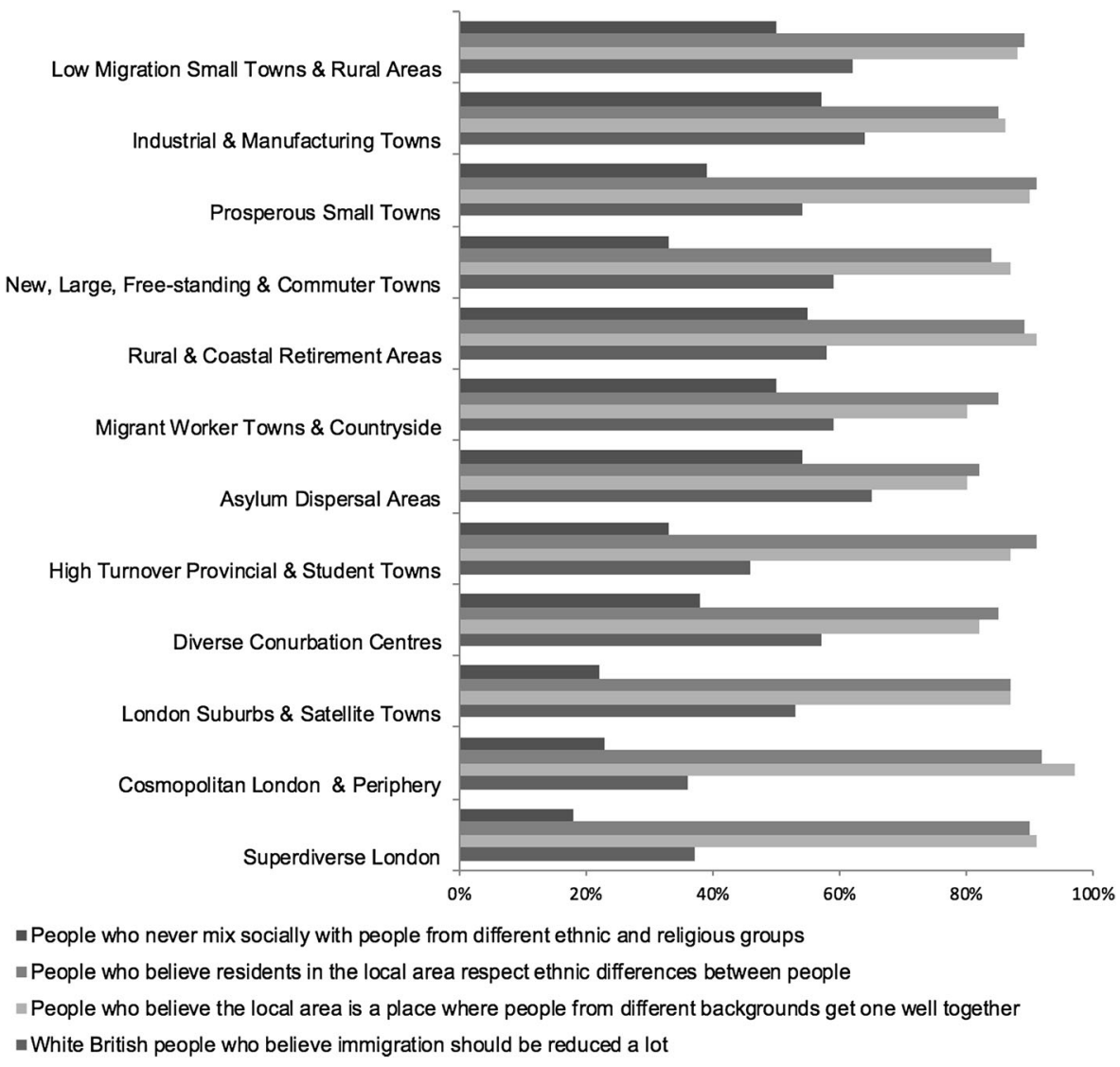

Fig. 3 Perceptions of cohesion and attitudes to ethnic mixing and immigration Source: DCLG and Ipsos MORI, Citizenship Survey, 2009-2011

with different levels of cohesion. Traditional ethnic minority settlement areas with high socio-economic diversity and high migration rates for migrants of different nationalities and migration streams are associated with higher levels of social cohesion and inter-ethnic social mixing. Local areas characterised by lower levels of cohesion, more negative attitudes towards immigration and lower levels of social mixing are also experiencing high migration rates. In these areas, higher migration rates are associated with a single group of migrantsasylum seekers or migrant workers - and there is little history of diversity and immigration. More socio-economically deprived areas are shown to have lower cohesion, a finding which is in line with previous studies (see Becares et al. 2011). This is likely to reflect the contribution of neighbourhood deprivation towards the depletion of social networks and poor community relations between groups through perceived competition for resources and feelings of relative deprivation (Robinson and Reeve 2006; Letki 2008). The classification indicates that areas with the lowest levels of cohesion are those with high levels of socioeconomic deprivation and below average levels of migration and population turnover.

One limitation of the classification presented in this paper relates to the heuristic nature of area classification development which means that the local authority groupings are dependent on the choice of variables and clustering methods (Dennett and Stillwell 2011). This classification, as with other area classifications, offers insights 
about the characteristics of populations at a particular time period. The ways in which immigration impacts across localities are likely to change over time since places are dynamic and change with changes in the composition of their population, the quality and condition of local housing, access to employment opportunities and public sector interventions. Where pressures are felt as a result of the formation of new migrant communities these would be expected to recede over time: social cohesion in local areas will improve as socio-economic divisions between communities diminish (Ratcliffe 2012). Improvements in the economic circumstances of local populations, and investments in resources in local areas such as housing, will minimise perceptions of competition for resources and improve community relations. In the long-term, increases in ethnic diversity are likely to promote contact, tolerance and understanding and improve social cohesion (Laurence and Heath 2008).

\section{Conclusion and Implications}

The analysis presented in this paper contributes to academic and policy considerations about the social impact of immigration on local communities. The paper proposes the development of an area classification framework to aid understanding of the national and local impacts of international migration in England and Wales. One of the main advantages of creating an area classification is that it takes into account the compositional differences of international migration across local areas to facilitate interpretation and assessments of the impact of migration needed to guide government policies (Migration Advisory Committee 2012). The classification can be used by policy analysts to examine how immigration policy interventions targeted at particular groups of migrants, for example, students, migrant workers or asylum seekers, are likely to affect service provision and cohesion in local areas. New releases of administrative and survey data on international migration can be used to update the classification to provide a systematic framework to monitor the impact of international migration flows over time. The additional utility of the classification as an analytical tool for understanding variations in key policy outcomes, for example health, housing, and education within types of areas with different migration profiles, can facilitate more effective targeting of policies. The implication of identifying groups of local authorities experiencing 'high' migration flows with different migration and socio-economic profiles is that different resource planning and allocation responses to migration will be required by local authorities in each classification group. Experiences of social cohesion were shown to differ across classification areas, and counter to current political discourses, we find little support for the proposition that areas experiencing high migration are areas with lower social cohesion. Instead, we show that compositional differences of immigration across different local area contexts determine different levels of cohesion. In ethnically diverse areas which have attracted diverse groups of immigrants there are generally more positive attitudes towards immigration and higher levels of cohesion than elsewhere in England and Wales. In contrast, urban areas with larger concentrations of disadvantaged groups such as asylum seekers, and rural and semi-rural areas which have attracted large numbers of recent migrant workers from the EU Accession countries exhibit lower cohesion levels. The implication for policy is that local authorities in Asylum Dispersal Areas and Migrant Worker Towns \& Countryside would benefit the most from interventions aimed at improving community cohesion and targeted responses to deal with pressures arising from increased flows of migration. 
A promising future direction for studies examining the relationship between ethnic diversity and social cohesion is the development of classification indicators, drawn from a range of data sources, which provide a more nuanced picture of immigration compared to single indicators of diversity which dominate existing research in this area (van der Meer and Tolsma 2014). The classification also provides a methodological and theoretical framework, for identifying comparative study areas to explore in-depth the local experiences of immigration, and the ways in which the interplay between the characteristics of migration and diversity and the characteristics of local communities impact on cohesion.

Acknowledgments This work was conceived during a 6-month ESRC Internship at the Migration and Border Analysis Unit at the Home Office Science Directorate and further developed with support from the Centre on Dynamics of Ethnicity (Grant ref: ES/K002198/1). I would like to acknowledge Home Office staff for their support, encouragement, and feedback throughout this work. I am also grateful to James Laurence, Rob Ford, and Brian Robson at the University of Manchester for their helpful comments on versions of this paper.

Open Access This article is distributed under the terms of the Creative Commons Attribution 4.0 International License (http://creativecommons.org/licenses/by/4.0/), which permits unrestricted use, distribution, and reproduction in any medium, provided you give appropriate credit to the original author(s) and the source, provide a link to the Creative Commons license, and indicate if changes were made.

\section{References}

Audit Commission. (2007). Crossing Borders - Responding to the local challenges of migrant worker. London: Audit Commission Publishing Team.

Becares, L., Stafford, M., Laurence, J., \& Nazroo, J. (2011). Composition, concentration, and deprivation. Exploring their association with social cohesion among different ethnic groups in the UK. Urban Studies, 48, 2771-2787.

Cheong, P., Edwards, R., Gouldbourne, H., \& Solomos, J. (2007). Immigration, social cohesion and social capital, a critical review. Critical Social Policy, 27(1), 24-49.

Dennett, A., \& Stillwell, J. (2010). Internal migration in Britain, 2000-01, examined through an area classification framework. Population, Space and Place, 16(6), 517-538.

Dennett, A., \& Stillwell, J. (2011). A new area classification for understanding internal migration in Britain. Population Trends, 145, 146-171.

Duffy, B., \& Frere-Smith, T. (2014). Perceptions and reality, public attitudes to immigration. London: Ipsos MORI.

Everitt, B., \& Dunn, G. (2001). Applied multivariate data analysis - second edition. London: Hodder Arnold.

Ford, R., \& Goodwin, M. (2017). A nation divided. Journal of Democracy, 28(1), 17-30.

George, A., Meadows, P., Metcalf, H., \& Rolfe, H. (2012). Impact of migration on the consumption of education and children's services and the consumption of health services, social care and social services, report to the migration advisory committee. London: MAC.

Green, A. E., Owen, D., \& Jones, P. (2007). The economic impact of migrant workers in west midlands. Coventry: University of Warwick.

House of Lords Select Committee on Economic Affairs. (2008). The economic impact of immigration, Volume 1 Report - Select Committee on Economic Affairs 2007/08. London: HMSO.

Institute of Community Cohesion. (2007). Estimating the scale and impacts of migration at the local level. London: LGA.

Kearns, A., \& Parkinson, M. (2001). The significance of neighbourhood. Urban Studies, 38, 2103-2110.

Laurence, J. (2011). The effect of ethnic diversity and community disadvantage on social cohesion: A multilevel analysis of social capital and interethnic relations in UK communities. European Sociological Review, 27, 70-89. 
Laurence, J., \& Heath, A. (2008). Predictors of community cohesion, multi-level modelling of the 2005 citizenship survey. London: CLG.

Letki, N. (2008). Does diversity erode social cohesion? Social capital and race in British neighbourhoods. Political Studies, 56(1), 99-126.

Livingston, M., Bailey, N., \& Kearns, A. (2008). People's attachment to place: The influence of neighbourhood deprivation. York: Joseph Rowntree Foundation.

Lymperopoulou, K. (2013). The area determinants of the location choices of new immigrants in England. Environment and Planning A, 45(3), 575-592.

Migration Advisory Committee. (2012). Analysis of the impacts of migration. London: UK Border Agency.

Office for National Statistics (ONS). (2005). Methods for national statistics 2001 area classification for local authorities, user guide. Available at: http://www.ons.gov.uk/ons/guide-method/geography/products/areaclassifications/ns-area-classifications/index/methodology-and-variables/local-authorities/index.html. Accessed 01 Jan 2016.

Pemberton, S. (2006). Economic migration from the EU A8 accession countries and the impact on lowdemand housing areas, opportunity or threat for housing market renewal pathfinder programmes in England? Urban Studies, 46(7), 1363-1384.

Pemberton, S., \& Stevens, C. (2007). Economic migration to Housing Market Renewal areas in North West England - opportunity or threat? MSIO Policy Report 4. Liverpool: Merseyside Social Inclusion Observatory.

Phillimore, J., \& Goodson, L. (2006). Problem or opportunity? Asylum seekers, refugees, employment and social exclusion in deprived urban areas. Urban Studies, 4310, 1-22.

Phillips, D. (2007). Ethnic and racial segregation, a critical perspective. Geography Compass, 1(5), 1138-1159.

Putnam, R. D. (2007). E Pluribus Unum: Diversity and community in the twenty-first century the 2006 Johan Skytte prize lecture. Scandinavian Political Studies, 30(2), 137-174.

Quillian, L. (1995). Prejudice as a response to perceived group threat, population composition and antiimmigrant and racial prejudice in Europe. American Sociological Review, 60(4), 586-611.

Quillian, L. (2014). Does segregation create winners and losers? Residential segregation and inequality in educational attainment. Social Problems, 61, 402-426.

Ratcliffe, P. (2012). Community cohesion: Reflections on a flawed paradigm. Critical Social Policy, 32(2), $262-281$.

Raymer, J., \& Giulietti, C. (2009). Ethnic migration between area groups in England and Wales. Area, 41(4), 435-451.

Robinson, D. (2010). The neighbourhood effects of new immigration. Environment and Planning A, 42(10), 2451-2466.

Robinson, D., \& Reeve, K. (2006). Neighbourhood experiences of new immigration, reflections from the evidence base. York: Joseph Rowntree Foundation.

Robinson, D., Reeve, K., \& Casey, R. (2007). The housing pathways of new migrants. York: Joseph Rowntree Foundation.

Robson, B., Lymperopoulou, K., \& Rae, A. (2008). People on the move: Exploring the functional roles of deprived neighbourhoods. Environment and Planning A, 40(11), 2693-2714.

Saggar, S., \& Somerville, W. (2012). Building a British model of integration in an era of immigration. London: Migration Policy Institute.

Saggar, S., Somerville, W., Ford, R., \& Sobolewska, M. (2012). The impacts of migration on social cohesion and integration. Final report to the migration advisory committee. London: Home Office.

Spicer, N. (2008). Places of exclusion and inclusion: Asylum seeker and refugee experiences of neighbourhoods in the UK. Journal of Ethnic and Migration Studies, 34(3), 491-510.

Sturgis, P., Brunton-Smith, I., Read, S., \& Allum, N. (2011). Does ethnic diversity erode trust? Putnam's hunkering down? Thesis reconsidered. British Journal of Political Science, 41(01), 57-82.

Sturgis, P., Brunton-Smith, I., Kuha, J., \& Jackson, J. (2014). Ethnic diversity, segregation and the social cohesion of neighbourhoods in London. Ethnic and Racial Studies, 37(8), 1286-1309.

van der Meer, T., \& Tolsma, J. (2014). Ethnic diversity and its effects on social cohesion. Annual Review of Sociology, 40, 459-478.

Vertovec, S. (2007). New complexities of cohesion in Britain, super-diversity, transnationalism and civilintegration. Wetherby: Communities and Local Government Publications.

Vickers, D., \& Rees, P. (2007). Creating the UK National Statistics 2001 output area classification. Journal of the Royal Statistical Society Series a-Statistics in Society, 170(2), 379-403.

Zorlu, A., \& Mulder, C. H. (2008). Initial and subsequent location choices of immigrants to the Netherlands. Regional Studies, 42(2), 245-264.

Publisher's Note Springer Nature remains neutral with regard to jurisdictional claims in published maps and institutional affiliations. 